\title{
ECONOMICS
}

\section{Assessment of the social target program}

\author{
V. A. Gordienko' ${ }^{1}$ E. V. Borvinko ${ }^{2}$ \\ ${ }^{1}$ University of Customs and Finance, Dnipro, Ukraine \\ 2.Dnipropetrovsk Medical Academy, Dnipro, Ukraine \\ Corresponding author. Email: vog1814@gmail.com
}

Paper received 26.01.20; Accepted for publication 11.02.20.

\section{https://doi.org/10.31174/SEND-HS2020-223VIII37-04}

Annotation. The mortality rate in Ukraine is 15.2 people per thousand citizens. Whereas the average European indicator is 6.2 people. Analysis of statistical information allows us to conclude that, for reasons of mortality, mortality from HIV/AIDS plays a significant role. Despite the efforts and modern means of counteracting the HIV epidemic, the developed regional target programs (CPU) require improvement, changing priorities, and informing society as the epidemic trends in the region. The authors propose, as a method of evaluating the CPU, the construction of an economic-mathematical model (EMM) of the dependence of the quality indicator on the indicator of resources. The assessment of the task "Ensuring the prevention of HIV infection, care and treatment for HIV-infected and AIDS patients in the Dnipropetrovsk region" CP "Health of the population of Dnipropetrovsk for the period 2015-2019" was carried out. The established inefficiency of the implementation of the CPU is explained by the low level of financing in the current economic situation of the country, and the non-optimal allocation of funds for the tasks of the CPU.

Keywords: program-target method (PCM), target program (CPU), HIV infection, AIDS patients, estimated indicators of CPU, economic and mathematical model (EMM).

Introduction. The basis of budget reforms that were carried out in the leading countries of the world were: medium-term budget planning and the allocation of financial resources to the final socially significant results. International practice has proven the success of the reforms. Every year, a significant number of targeted programs (CPU) are approved by the local budgets of Ukraine. The formation of such a program involves the application of the methodology of program-target planning [1].

PCM require a clearly formulated goal, specific objectives and the formation of estimated indicators, in particular: product, costs, efficiency and quality [1]. The study of regional CPUs in the Dnipropetrovsk region revealed that in almost all programs only the indicator of expenses is ensured, which is formed from the achieved level, aimed at formal activities and does not systematically follow from the goals and objectives of the program. There are simply no other estimates. In this case, how will the achievement of the program objective be assessed? There is an opportunity to direct funds not for the implementation of the program, but for another purpose. Therefore, there is a need to use effective methods for assessing the effectiveness of CPU implementation.

A brief overview of publications on the topic. A series of publications by Russian and foreign scholars is devoted to the topic of budget management for the PCM [2-4]. Vergeichik V describes the experience of conducting a CPU audit [2]. Pleskach V.L. and Zhelyabovskiy Yu.G. [3] determine the theoretical basis for the use of PCM, and Chugunov I.Ya. and Zapatrina I.V. [4] consider the history of the introduction of the method and its significance for the development of the budget system. But the analysis of the assessment of the practical application of the method in planning local budgets in Ukraine is still an open question.

Purpose of research. The purpose of the article is to identify problems that complicate the demographic situation in the Dnipropetrovsk region. Development of a method for evaluating CPU efficiency using economic - mathematical methods (EMM).
Materials and methods. Information of the Main Department of Statistics in the Dnipropetrovsk region, regional CPUs and their tasks, systemic, socio-economic and correlation - regression analysis.

Results and its discussion. The current state of the process of reproduction of the population of the Dnipropetrovsk region can be described as a demographic crisis. The difficult demographic situation is caused by many factors, one of which is the deterioration of socio-economic conditions, in particular mortality from HIV/AIDS. In the period 2010-2019. The population of the region decreased by 149 thousand. People, including urban - by 110.8 thousand, rural - by 38.2 thousand (Table 1) [5]. In the period 2010-2019, the population of the region decreased by 149 thousand people, including urban - by 110.8 thousand, rural - 38.2 thousand.

Table 1. The population of the region at the period 2010-2019

\begin{tabular}{|c|c|c|c|}
\hline \multirow{2}{*}{ Year } & \multicolumn{3}{|c|}{ Population, thousand people } \\
\cline { 2 - 4 } & total & urban & rural \\
\hline 2010 & 3355,5 & 2801,3 & 554,2 \\
\hline 2011 & 3336,5 & 2785,4 & 551,1 \\
\hline 2012 & 3320,3 & 2772,2 & 548,1 \\
\hline 2013 & 3307,8 & 2763,2 & 544,6 \\
\hline 2014 & 3292.4 & 2751,8 & 540,6 \\
\hline 2015 & 3276,6 & 2740,0 & 536,6 \\
\hline 2016 & 3254,9 & 2722,1 & 532,8 \\
\hline 2017 & 3230,4 & 2701,1 & 529,3 \\
\hline 2018 & 3231,1 & 2707,0 & 524,1 \\
\hline 2019 & 3206,5 & 2690,5 & 516,0 \\
\hline The pace of change & $-4,4$ & -4 & $-6,9$ \\
\hline 2010 until 2019 $(\%)$ & & & \\
\hline
\end{tabular}

Graphically, the change in the population of the region is presented in Fig. 1.

According to a model built on the dynamics of the population of the region, with a $99 \%$ confidence, the number will decrease by almost 16.4 thousand people every year. The negative dynamics of the region's population is also 
affected by the HIV/AIDS epidemic. Ukraine remains the leader in Europe in terms of the spread of HIV infection. According to UNAIDS experts, about 240,000 people live in Ukraine with HIV infection. And only every second one knows about his diagnosis - as of October 1, 2019, 136849 HIV-positive patients are registered in Ukraine. Since 2008, Ukrainians are most often infected through unprotected sex. If in 200533 percent of people who were infected with HIV were infected through sexual contact, in 2012 this percentage rose to 51 . For the first time, more than half of new HIV infections occurred through unprotected sex. In 2018, this figure was 66 percent. Most cases of HIV infection in Ukraine today are recorded in young people aged 15 to 30 years. In 2012, for the first time in the history of Ukraine, the HIV/AIDS epidemic slowed down according to official statistics in 2012, the rate of spread of HIV infection (the number of new cases of HIV) was lower than in 2011. This was the result of national programs for vulnerable groups and large-scale HIV/AIDS prevention information campaigns. Due to the reduction in AIDS programs in 2013-2017, the pace of the epidemic began to grow again. According to experts, since 2014 the epidemic situation in our country has rapidly deteriorated. One of the main indicators by which the development of the epidemic is monitored is the number of new cases of HIV infection. In 2017, this indicator grew by 6.6 percent compared to 2016 this corresponds to the dynamics of the epidemic, as it was about 10 years ago.

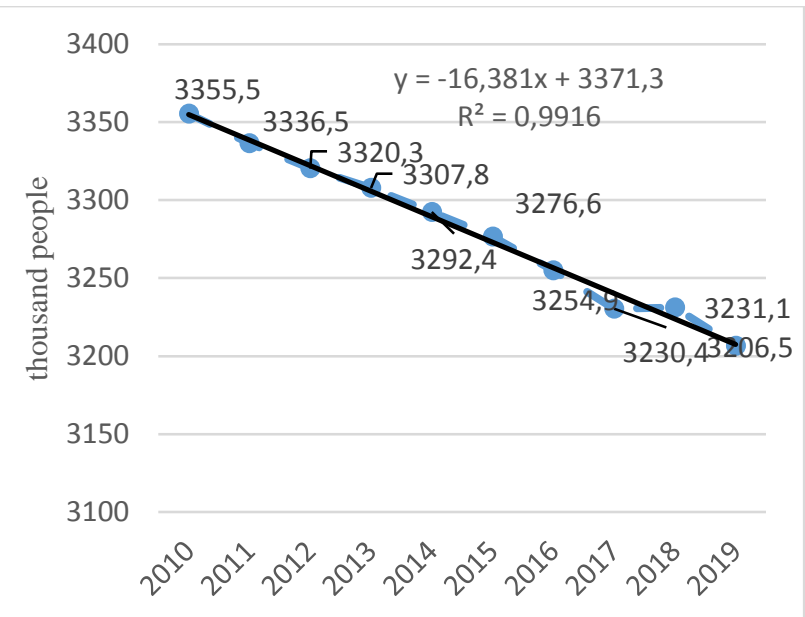

Fig. 1. The dynamics of the population of the region in 2010-2019.

In 2018, for the first time, a slowdown in the epidemic was recorded (by 0.52 percent) already on a new statistical basis - without taking into account data from the Crimea and regions of Donetsk and Lugansk regions not controlled by Ukraine. The dynamics of AIDS mortality in the Dnipropetrovsk region and Ukraine are presented in Fig. 2.

The dynamics of AIDS mortality in the Dnipropetrovsk region significantly exceeds the indicator of Ukraine (regression coefficients correspond to 4.56 and 1.01). According to the constructed models, with a $85 \%$ confidence, mortality in the region and Ukraine will increase by 4.56 and 1.01 people each year, respectively. per 100 thousand people. Therefore, the fight against this problem should be addressed immediately. As you know, an effective method of solving problems is the use of PCM.

The final stage of the implementation of the PCM is to evaluate the effectiveness of the implementation of the target program. One of the possible methods that allows you to evaluate the results of the implementation of the target program is to build an EMM of the dependence of the quality indicator on the resource indicator [6].

Dynamics of AIDS mortality in the Dnipropetrovsk region and Ukraine (per 100 thousand people)

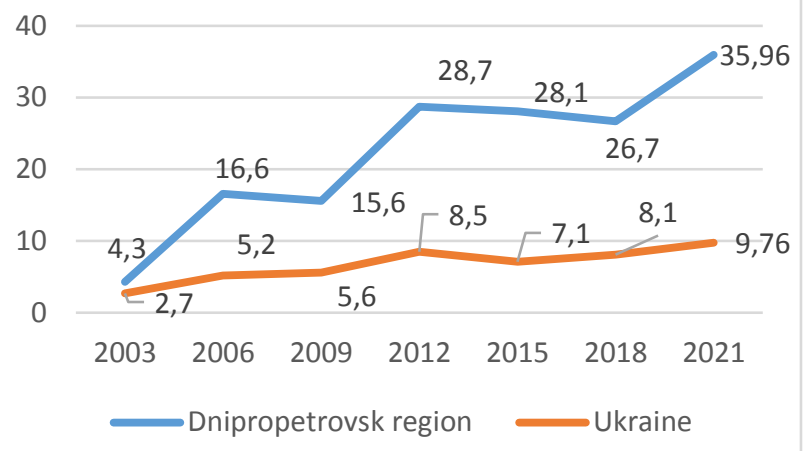

Fig. 2. Dynamics of AIDS mortality in the Dnipropetrovsk region and Ukraine.

The main indicator of quality in CPU is the number of cases of HIV infection and AIDS deaths. An indicator of resources is the cost of fulfilling the task "Ensuring HIV prevention, care and treatment for HIV-infected and AIDS patients in the Dnipropetrovsk region" CPU "Health of the population of Dnipropetrovsk for the period 20152019."The hypothesis is being tested - the funds for the program are spent effectively in the case of a close positive relationship between the costs of the program and the incidence and mortality from tuberculosis and AIDS. The problem of studying the interrelations of economic indicators is one of the most important in economic analysis and can be implemented using EXCEL spreadsheets. The data used for the calculations are shown in table 2.

Table 2. Data for calculations.

\begin{tabular}{|c|c|c|}
\hline $\begin{array}{c}\text { Expenses for } \\
\text { the CPU } \\
\text { task, mln. }\end{array}$ & $\begin{array}{c}\text { The number of cases } \\
\text { of HIV infection per } \\
\text { 100 thousand people. }\end{array}$ & $\begin{array}{c}\text { Mortality from } \\
\text { AIDS, per 100 } \\
\text { thousand people }\end{array}$ \\
\hline 32,5 & 88 & 28,1 \\
\hline 29,7 & 94,8 & 30,9 \\
\hline 30,9 & 110,5 & 27,0 \\
\hline 32,4 & 107 & 26,7 \\
\hline 40,3 & 117,3 & 26,2 \\
\hline
\end{tabular}

Based on the data presented, two EMMs were constructed that characterize the relationship of indicators (Fig. 3-4).

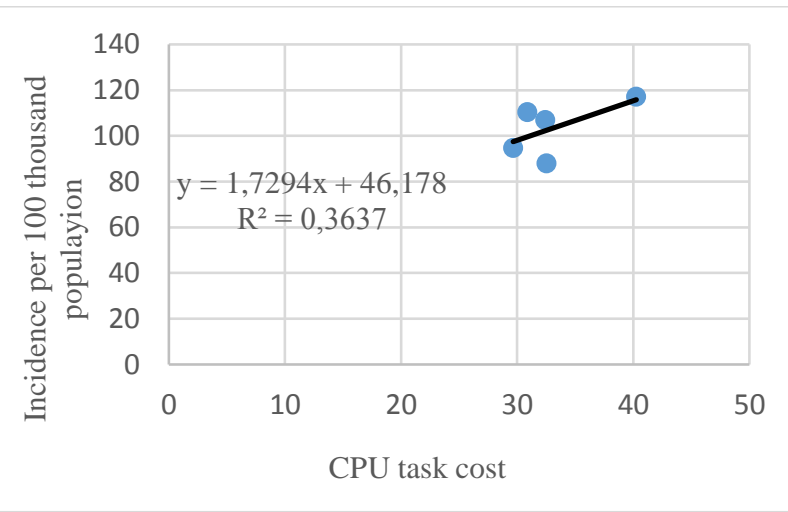

Fig. 3. The dependence of the incidence on the cost of the task of the CPU. 


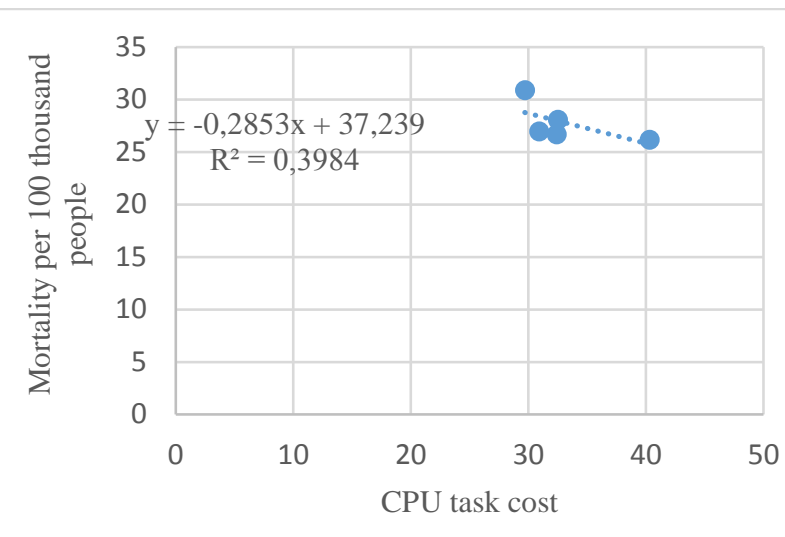

Fig. 4. The dependence of mortality of patients on the cost of the task of the CPU.

Assessment of model parameters is presented in table 3.

Table 3. Estimation of model parameters.

\begin{tabular}{|l|l|l|l|}
\hline \multicolumn{3}{|c|}{ Model 1 } & \multicolumn{2}{|c|}{ Model 2 } \\
\hline $\mathrm{a}_{1}=1,7294$ & $\mathrm{a}_{0}=46,178$ & $\mathrm{~b}_{1}=-0,2853$ & $\mathrm{~b}_{0}=37,239$ \\
$\mathrm{Sa}_{1}=1,32$ & $\mathrm{Sa}=44,06$ & $\mathrm{Sb}_{1}=0,20238$ & $\mathrm{Sb}_{0}=6,7529$ \\
$\mathrm{R}^{2}=0,36$ & $\mathrm{~S}=10,96$ & $\mathrm{R}^{2}=0,398$ & $\mathrm{~S}=1,682$ \\
$\mathrm{~F}=1,71$ & $\mathrm{df}=3$ & $\mathrm{~F}=1,99$ & $\mathrm{df}=3$ \\
$\mathrm{Ssreg}=205,94$ & $\mathrm{Ssresid}=360,31$ & $\mathrm{Ssreg}=5,621$ & $\mathrm{Ssresid}=8,487$ \\
\hline
\end{tabular}

Analyzing the estimates of the parameters of the models, we can conclude that there is no connection between the indicators (respectively, model $1-\mathrm{R} 2=0.36$, model $2-\mathrm{R} 2$
$=0.398)$. The lack of communication proves the inefficiency of the task "Ensuring the prevention of HIV infection, care and treatment for HIV-infected and AIDS patients in the Dnipropetrovsk region" CPU "Health of the population of Dnipropetrovsk for the period 2015-2019." This can mainly be explained by the very low level of CPU funding. It should also be noted that the AIDS control centers have been transferred to the rank of the tasks of the regional program in which there are no indicators due to which the results of the fight against AIDS can be estimated [7].

Conclusions. Having analyzed the methods for evaluating targeted programs, we believe that the main indicator is a quality indicator, only it is an indicator that answers the question - is the goal achieved? But even in this way (using a quality indicator), it is not always possible to objectively evaluate the cost-effectiveness of achieving a program goal, which is a consequence of a significant fluctuation of economic and social indicators over time. In this case, the conclusion will depend on whether the minimum or maximum fluctuations in the quality indicator will have to be evaluated. It is possible to more accurately evaluate the effectiveness of expenditures by constructing an economic - mathematical model (EMM) of the dependence of expenditures on the target program (during its implementation) and quality indicators for the same period. The problem of studying the interconnections of economic indicators is one of the most important in economic analysis and can be implemented using EXCEL spreadsheets

\section{ЛІТЕРАТУРА}

1. Бюджетний Кодекс України. [Електронний ресурс] - Режим доступу: https://zakon.rada.gov.ua/laws/show/2456-17.

2. Вергейчик О. Реалізація національної програми боротьби 3 туберкульозом у Дніпропетровській області//Державне управління та місцеве самоврядування:Збірник наукових праць.- Дніпропетровськ:Дніпропетровський регіональний інститут державного управління.2009. Вип.1(1).- Режим доступу до збірника: http://whttp://www.nbuv.gov.ua/portal/soc_gum/Dums/200901 .

3. Плескач В.Л. Сучасні підходи щодо фінансового регулювання механізму реалізації цільових програм/Плескач В.Л., Желябовский Ю.Г.//Фінанси України, 2009. - №1.- С. 58-73.

4. Чугунов І.Я. Розвиток програмно-цільового методу планування бюджету/Чугунов І.Я., Запатріна І.В.//Фінанси України, 2008, № 5.- С. 3-14.

5. Офіційний сайт Головного управління статистики у Дніпропетровській області[Електронний ресурс] - Режим доступу: http:// www. dneprstat. gov. ua (дата звернення 20. 01.2020).

6. Гордієнко В.О. Програмно - цільовий метод - інструмент побудови сучасної економіки: монографія /В.О. Гордієнко. - Дніпропетровськ: ДДФА, 2014. - 268 с.

7. Обласна програма “'Здоров’я населення Дніпропетровщини на період 2015-2019 роки " [Електронний ресурс] - Режим доступу: $\quad$ https://adm.dp.gov.ua/ua/dniprooda/prooda/departamenti-ta-upravlinnya/departament-ohoronizdorovya (дата звернення 20. 01.2020).

\section{REFERENCES}

1. Budget Code of Ukraine. [Electronic resource] - Access mode: https://zakon.rada.gov.ua/laws/show/2456-17.

2. Verheychyk O. Implementation of the National Tuberculosis Control Program in Dnipropetrovsk Region//State Administration and Local Self-Government: Collection of Scientific Papers.- Dnipropetrovsk: Dnipropetrovsk Regional Institute of Public Administration, 2009. - Issue 1 (1). [Electronic resource] - Access mode: http://whttp: //www.nbuv.gov.ua/portal/soc_gum/Dums/2009-01.

3. Pleskach V.L, Zhelyabovsky Yu.G. Modern approaches to financial regulation of the mechanism of implementation of targeted programs. Finance of Ukraine, 2009. No1.- Page. 5873.

4. Chughunov I.Ja., Zapatrina I.V. Development of programtargeted method of budget planning. Finansy Ukrajiny. No 5.Page 3-14.

5. Official site of the Main Directorate of Statistics in Dnipropetrovsk Oblast [Electronic resource] - Access mode: http:// www.dneprstat.gov.ua.

6. Gordienko VA Program - target method - a tool for building a modern economy: monograph/V.O. Gordienko. Dnepropetrovsk: DSFA, 2014. - 268 p..

7. Regional program "Health of the population of Dnipropetrovsk region for the period 2015-2019", [Electronic resource] - Access mode: https://adm.dp.gov.ua/ua/dniprooda/prooda/departamenti-ta-upravlinnya/departament-ohoronizdorovya. 